\title{
ANALISIS KOMPETENSI DAN PELAKSANAAN SUPERVISI AKADEMIK PENGAWAS SEKOLAH MENENGAH DI KOTA TUAL PROVINSI MALUKU
}

\author{
Oleh : Abraham Amram Rahawarin \\ Universitas Negeri Makassar Jl. Bonto Langkasa, Makassar- 90222, \\ Tlp.(04011) 355288, E-mail: Pasca@unm.ac.id, Wibsite://www.pps.unm.ac.id
}

\begin{abstract}
ABSTRAK
Supervisi akademik sebagai salah satu sarana untuk membantu meningkatkan kualitas profesional tenaga pendidik, belum banyak dirasakan manfaatnya oleh para guru. Penelitian ini bertujuan untuk mendeskripsikan analisis kompetensi dan pelaksanaan supervisi akademik pengawas Sekolah Menengah di Kota Tual Provinsi Maluku. Penelitian ini adalah penelitian deskriptif dengan menggunakan pendekatan kualitatif.

Teknik pengambilan data melalui observasi, wawancara, dokumentasi sebagai data utama dan kuesioner sebagai data pendukung. Subyek penelitian ini adalah koordinator pengawas, kepala sekolah dan guru sekolah Menengah di Kota Tual Provinsi Maluku.

Hasil penelitian menyimpulkan bahwa kompetensi dan pelaksanaan supervisi akademik pengawas Sekolah Menengah di Kota Tual Provinsi dinilai tidak efektif, karena kegiatan penyusunan program dan hasil laporan pengawas, kegiatan pemantauan, penilaian, pembimbingan dan pelatihan profesional guru tidak sesuai dengan pedoman tugas pengawasan. Yang menjadi faktor penyebabnya adalah motivasi, kompetensi dan kemampuan pengawas rendah, komunikasi tidak lancar, upaya pemberdayaan Kepala Dinas Pendidikan belum optimal, kompleksitas dan beban kerja pengawas berat, biaya, dan daya ingat pengawas yang berkurang karena dipengaruhi oleh faktor usia yang semakin lanjut. Perlu penelitian lebih lanjut untuk mengetahui adanya hubungan dan
\end{abstract}


pengaruh faktor-faktor tersebut terhadap pelaksanaan supervisi akademik pengawas Sekolah Menengah di Kota Tual Provinsi Maluku.

Kata Kunci : Analsis Kompetesi dan Pelaksanaan supervisi akademik pengawas.

\begin{abstract}
This study aims to describe the analysis of competence and the implementation of academic supervisors in secondary school in Tual of Maluku Province.

This study is a qualitative study using a deskriptive approach. Tecniques used in collecting the data through observation, interviews, and documentation as the main data and questionnaire as the supporting data. The subjects of the study were coodinator of supervisors, principals, and teachers of secondary schools in Tual in maluku Province.

The results of the study concluded that the competence and implemantation of academic supervision of supervisiors in secondary school in Tual in Maluku Province was conducted ineffectively because the supervisiors were less involved in the training/coaching which gave impact on programming and supervisory reports. The activities of monitoring, assessment, guidance, and professional training of teachers were not is accordance with the guidelines and supervisory duties. The faktors were motivation, competence and the ability of supervisiors were still in low category, the empowerment of education department was yet optimal, the complexity and workload of supervisiors were hard, costs, and certain conditions gave influence on supervisiors' activities.
\end{abstract}

Key word : Competence Analysis And Implementation Of Academic Supervision 


\section{PENDAHULUAN}

Pendidikan merupakan hal yang sangat penting dalam kehidupan manusia dan sebagai wahana pengembangan Sumber Daya Manusia (SDM). Melalui pendidikan manusia dapat melepaskan diri dari keterbelakangan. Pendidikan mampu menanamkan kapasitas baru bagi manusia dalam mempelajari pengetahuan dan ketrampilan baru, sehingga dapat memperoleh manusia yang produktif (Sutarto,1999)

Dalam Undang-undang Republik Indonesia Nomor 20 Tahun 2003 tentang Sistem Pendidikan Nasional pada Bab I pasal 1 ayat 1 berbunyi bahwa Pendidikan merupakan usaha sadar dan terencana untuk mewujudkan suasana belajar dan proses pembelajaran agar peserta didik secara aktif mengembangkan potensi dirinya untuk memiliki kekuatan agama, pengendalian diri, kepribadian, kecerdasan, akhlak mulia, serta kerterampilan yang diperlukan dirinya, masyarakat, bangsa dan negara.

Selaras dengan hal itu, maka kedudukan dan peran guru dan pengawas sekolah semakin dibutuhkan. Profesionalisme guru dan pengawas sekolah mutlak diperlukan untuk keberhasilan pembelajaran dan peningkatan mutu pendidikan. Dalam rangka meningkatkan mutu pendidikan di Indonesia, maka pemerintah telah menetapkan Standar Nasional Pendidikan yang telah dituangkan dalam Peraturan-pemerintah Nomor 19 Tahun 2005. Menurut Sudjana (2011: iii) delapan Standar Nasional Pendidikan adalah: (a) ) standar isi, (b) standar proses (c) standar kompetensi lulusan, (d) standar pendidik dan tenaga kependidikan, (e) standar sarana dan prasarana, (f) standar pengelolaan pendidikan (g) standar pembiayaan pendidikan dan (h) standar penilaian pendidikan. Standar pendidik dan tenaga kependidikan berisi kualifikasi akademik dan kompetensi yang secara minimal harus dikuasai dan dimiliki oleh pendidik dan tenaga kependidikan terutama pada pendidikan dasar dan menengah (Iskandar and Rudi 2017).

Tenaga kependidikan yang dimaksud adalah terdiri atas tenaga kepala sekolah, pengawas sekolah dan tenaga lainnya seperti laboran, tenaga perpustakaan sekolah, tenaga administrasi sekolah dan tenaga lainnya. Dengan 
demikian, dalam melaksanakan delapan standar nasional pendidikan sebagai rujukan peningkatan mutu pendidikan, maka ada tiga pelaku pendidikan yang harus bekerja secara sinergis yakni guru, kepala sekolah, dan pengawas sekolah. Sebagaimana Sudjana (2011: iii) menjelaskan bahwa, guru diberdayakan dan dibina oleh kepala sekolah agar melaksanakan tugas pokok dan tanggung jawabnya secara optimal. Pengawas sekolah melaksanakan supervisi terhadap pelaksanaan tugas guru dan kepala sekolah. Oleh sebab itu, pengawas sekolah harus memiliki konsep-konsep supervisi pendidikan serta menerapkannya dalam melaksanakan supervisi akademik dan supervisi manajerial. Konsep-konsep supervisi pendidikan tersebut berguna untuk peningkatan mutu pendidikan di sekolah.

Pengawas sekolah memiliki peranan yang sangat signifikan dan strategis dalam proses dan hasil pendidikan yang bermutu di sekolah. Dalam konteks ini peran pengawas meliputi pemantauan, supervisi, evaluasi, pelaporan, dan tindak lanjut pengawas yang harus dilaksanakan secara teratur dan berkesinambungan. Tugas pokok pengawas sekolah adalah melaksanakan tugas pengawasan akademik dan manajerial pada satuan pendidikan yang meliputi penyusunan program pengawasan, pelaksanaan pembinaan, pemantauan pelaksanaan delapan standar nasional pendidikan, penilaian, pembimbingan, dan pelatihan profesional guru, mengevaluasi hasil pelaksanaan program pengawasan dan pelaksanaan tugas kepengawasan di daerah khusus.

Berdasarkan kompetensi tersebut di atas, pengawas sekolah dituntut agar mampu membantu guru dan kepala sekolah dalam pelaksanaan tugas di sekolah terutama yang berhubungan dengan tugas-tugas akademik maupun tugas-tugas manajemen. Pengawas sekolah memiliki posisi dan peran strategis dalam upaya peningkatan mutu pendidikan di sekolah. Posisi strategis yang dimiliki pengawas sekolah disebabkan karena pengawas berfungsi sebagai pelaksana teknis fungsional di bidang pengawasan akademik dan manajerial pada sejumlah sekolah yang telah ditetapkan yang tercantum dalam (Permeneg PAN dan RB No. 21 Tahun 2010 Tentang Jabatan Fungsional Pengawas Sekolah dan Angka Kredit). 
Peran strategis yang dimiliki pengawas sekolah karena pengawas sekolah adalah sebagai penjamin mutu pendidikan di sekolah menurut (Permendiknas No. 63 Tahun 2009 Tentang Sistem Penjamin Mutu Pendidikan). Posisi dan peran strategis yang dimiliki oleh pengawas sekolah ternyata tidak sepenuhnya di pahami secara benar olah sebagian pengawas sekolahnya sendiri maupun oleh sebagian pemangku kepentingan pendidikan lainnya.

Kegiatan Supervisi Pengawas Sekolah akan berpengaruh secara psikologis terhadap kinerja guru, guru yang puas dengan pemberian supervisi pengawas sekolah yang tinggi maka ia akan bekerja dengan sukarela yang akhimya dapat membuat produktivitas kerja guru meningkat. Tetapi jika guru kurang puas terhadap pelaksanaan supervisi pengawas sekolah yang rendah maka guru dalam bekerja kurang bergairah, hal ini mengakibatkan kinerja dan prestasi guru akan menurun.

Sementara itu, berdasarkan informasi dari kepala sekolah dan beberapa guru Sekolah Menengah di Kota Tual Provinsi Maluku pada umumnya menyatakan bahwa para pengawas dinilai jarang melakukan kunjungan ke sekolah-sekolah binaannya. Para guru belum merasakan manfaat yang nyata dalam peningkatan kualitas pembelajaran dari kegiatan supervisi akademik yang dilakukan oleh pengawas. Masih terdapat guru-guru yang kebingungan dalam membuat perangkat pembelajaran, contoh kasus dalam membuat rencana pelaksanaan pembelajaran (RPP). RPP antara satu guru dengan guru lainnya dalam satu sekolah yang sama, masih terdapat perbedaan baik format maupun isi, hal ini menunjukan belum adanyan standar dalam pembuatan RPP yang dijadikan sebagai acuan bagi para guru sekolah menengah di Kota Tual Provinsi Maluku. Penentuan standar penyusunan RPP ini merupakan salah satu tanggung jawab dari para pengawas dalam membina profesiaonalitas para guru binaannya. Fenomena ini memberikan gambaran bahwa salah satu kegiatan pelaksanaan pembinaan dari pengawas dalam kegiatan kompetensi dan pelaksanaan supervisi akademik sekolah menengah di kota Tual Provinsi Maluku belum efektif. Kondisi tersebut apabila terus dibiarkan akan mengakibatkan penurunan kualitas profesional guru-guru, penurunan prestasi belajar 
para siswa dan muaranya pada rendahnya kualitas pendidikan sekolah menengah di Kota Tual Provinsi Maluku.

Berdasarkan latar belakang masalah penelitian di atas, maka dirumuskan: Bagaimanakah kompetensi dan Pelaksanaan supervisi akademik yang dimiliki oleh pengawas sekolah menengah berdasarkan persepsi guru di Kota Tual Provinsi Maluku?

Dari pertanyaan penelitian yang telah dikemukakan di atas, maka yang menjadi tujuan yang ingin dicapai adalah Untuk mengetahui kompetensi dan pelaksanaan supervisi akademik yang dimiliki pengawas sekolah menengah berdasarkan persepsi guru di Kota Tual Provinsi Maluku, Adapun manfaat penelitian ini terdiri dari manfaat secara teoritis dan manfaat praktis.

\section{Metode Penelitian}

Penelitian ini berfokus pada kompetensi dan pelaksanaan supervisi akademik pengawas Sekolah Menengah berdasarkan persepsi guru di Kota Tual Provinsi Maluku. Untuk menyatukan persepsi, maka deskripsi terhadap objek yang menjadi fokus penelitian antara lain Kompetensi supervisi akademik yang dimiliki pengawas sekolah menengah di Kota Tual Provinsi Maluku merupakan gambaran kemampuan kompetensi supervisi akdemik pengawas yang diperoleh melalui observasi yang kemudian dikonfirmasi kembali melalui proses wawancara dan dokumentasi terhadap koordinator pengawas sekolah, kepala sekolah, dan guru dengan memperhatikan indikator pemantauan, penilaian, dan pelatihan. Pelaksanaan supervisi akademik pengawas sekolah menengah di Kota Tual Provinsi Maluku merupakan deskripsi pelaksanaan supervisi akademik yang meliputi pemantauan pelaksanaan 4 standar nasional pendidikan (standar isi, standar proses, standar kompetensi lulusan, dan standar penilaian pendidikan), penilaian kinerja dan pembimbingan terhadap guru.

Untuk mendapatkan informasi tentang data yang dibutuhkan dalam penelitian ini, teknik pengumpulan data yang digunakan adalah Observasi dilakukan untuk mengamati secara langsung situasi dan kondisi pengawas 
sekolah melaksanakan supervisi akademik terhadap guru pada saat proses pembelajaran berlangsung di kelas. Sehingga proses penarikan kesimpulan dapat dipertanggung jawabkan validitasnya. Wawancara dimaksud untuk memperoleh data kualititf serta beberapa informasi dari informen, informen dalam penelitian ini adalah koordinator pengawas, kepala sekolah dan guru. Pertanyaan-pertanyaan yang digunakan dalam wawancara berhubungan dengan kompetensi dan pelaksanaan supervisi akademik pengawas sekolah menengah di Kota Tual Provinsi Maluku, yang meliputi pemantauan terhadap 4 standar nasional pendidikan (standar isi, standar proses, standar kompetensi kelulusan dan standar penilaian pendidikan), penilaian dan pembinaan terhadap guru. Dokumentasi peneliti mengartikan sebagai data tertulis yang diperoleh dari obyek penelitian seperti jumlah guru, dokumen yang disusun oleh pengawas, maupun sekolah yang meliputi, pedoman instrumen supervisi pengawas, perangkat pembelajaran guru, dan dokumen lain yang berkaitan dengan penelitian ini. Kuesioner Untuk mengetahui kompetensi dan pelaksanaan supervisi akademik pengawas sekolah menengah berdasarkan persepsi guru di Kota Tual Provinsi Maluku yang meliputi dimensi pemantauan, penilaian dan pembinaan/pelatihan.

Teknik analisis data yang digunakan dalam penelitian ini adalah analisis deskriptif untuk memperoleh gambaran mengenai kompetensi dan pelaksanaan supervisi akademik yang dimiliki pengawas sekolah menengah berdasarkan persepsi guru di Kota Tual Provinsi maluku. Data kualitatif dianalisis sesuai dengan pendapat Miles dan Huberman (Sugiyono, 2010: 338) yang membagi dalam tiga tahap kegiatan, yaitu reduksi data, penyajian data, dan penarikan kesimpulan. Dengan langkah-langkah sebagai berikut: Reduksi data, Dimaksudkan sebagai proses pemilihan, pemusatan perhatian pada penyederhanaan, pengabstrakan, dan transformasi data kasar yang muncul dari catatan-catatan yang tertulis di lapangan. selanjutnya membuat transkrip data yang penting dan membuang data yang tidak penting kemudian ditranskripkan sebagai data penelitian. Dalam mereduksi data selalu berpatokan kepada tujuan yang akan dicapai. Penyajian data, Penyajian data penelitian ini dilakukan untuk 
mengumpulkan data yang teroganisir dan dikategori ditulis kembali, sehingga memungkinkan adanya penarikan kesimpulan dan pengambilan tindakan berdasarkan pemahaman yang didapat dari penyajian-penyajian tersebut yang terdiri dari atas matriks, grafik, jaringan dan bagan. Semua dirancang guna menggabungkan informasi yang tersusun dalam suatu bentuk yang terpadu dan mudah diraih. Kesimpulan dan verifikasi, Dimaksudkan sebagai proses pengambilan kesimpulan dilakukan setelah peneliti mengumpulkan data dengan melakukan pencatatan keteraturan, pola-pola, penjelasan, konfigurasi-konfigurasi yang mungkin, alur sebab akibat dan proposisi. Kesimpulan yang ditarik mulamula belum jelas kemudian meningkat menjadi lebih rinci dan mengakar dengan kokoh sehingga nampak titik terangnya. Singkatnya, makna-makna yang muncul dari data harus diuji kebenarannya, kekokohannya dan kecocokannya yang merupakan validitasnya.

Data kuantitatif yang diperoleh dari hasil kuisioner sebagai data pendukung dianalisis dengan menggunakan analisis deskriptif dalam bentuk tabel distribusi frekuensi, mean, median, modus standar deviasi, varian, dan skor maksimum dan minimum. Analisis deskriptif dimaksudkan untuk menjelaskan tingkat persepsi guru terhadap kompetensi dan pelaksanaan supervisi akademik pengawas sekolah menengah di Kota Tual Provinsi Maluku.

\section{Hasil Penelitian}

Deskripsi data hasil penelitian dimaksudkan untuk memberikan gambaran umum mengenai penyebaran/distribusi data, baik berupa ukuran penyebaran, ukuran pemusatan, maupun distribusi frekuensi. Setelah diolah dari data mentah dengan menggunakan metode statistik deskriptif, nilai-nilai yang akan disajikan adalah nilai rata-rata, simpangan baku, modus, median, varians, dan distribusi frekuensi, serta histogram.

Berdasarkan variabel yang ada dan merujuk kepada masalah pokok penelitian, maka deskripsi data dapat dikelompokkan menjadi dua bagian yaitu: 
(1) kompetensi pengawas sekolah, dan (2) Pelaksanaan Supervisi Akademik Pengawas Sekolah Menengah di Kota Tual Provinsi Maluku.

Hasil perhitungan data statistik deskriptif masing-masing variabel secara lengkap dapat dilihat pada lampiran bagian akhir tesis ini. Selanjutnya, uraian singkat hasil analisis statistik deskriptif mengenai Kompetensi dan Pelaksanaan Supervisi Akademik Pengawas Sekolah Menengah di Kota Tual Provinsi Maluku dapat dikemukakan sebagai berikut:

Berdasarkan hasil analisis deskriptif diperoleh ukuran pemusatan tentang Kompetensi Pengawas Sekolah Menengah di Kota Tual Provinsi Maluku, yaitu skor rata-rata $($ mean $)=57,14 ;$ median $=59,00 ;$ dan modus $=59$. Hasil ini bersesuaian dengan distribusi frekuensi dan persentase yang menunjukkan bahwa Kompetensi Pengawas Sekolah Menengah di Kota Tual Provinsi Maluku berkisar 48,23 \% Dengan demikian secara kualitatif, Kompetensi Pengawas Sekolah Menengah di Kota Tual Provinsi Maluku termasuk kategori sedang.

Selanjutnya, dari hasil analisis statistik deskriptif diperoleh ukuran penyebaran, yaitu skor tertinggi sebesar 78 dan skor terendah sebesar 36, dan varians sebesar 102,170. Berdasarkan perolehan ukuran-ukuran tersebut yang relatif besar, maka dapat dikatakan bahwa penyebaran data variabel Kompetensi Pengawas Sekolah Menengah di Kota Tual Provinsi Maluku, cenderung bervariasi. Hal ini berarti data yang diperoleh dalam penelitian tersebar pada tiga kategori, yaitu: rendah, sedang, dan tinggi.

Adapun distribusi frekuensi dan persentase variabel Kompetensi Pengawas Sekolah Menengah di Kota Tual Provinsi Maluku dapat dilihat pada tabel sebagai berikut: 
Tabel 4.1. Distribusi Frekuensi dan Persentase Kompetensi Pengawas Sekolah Menengah di Kota Tual Provinsi Maluku

\begin{tabular}{cccc}
\hline Interval & Kategori & Frekuensi & $\begin{array}{c}\text { Persentase } \\
\text { (\%) }\end{array}$ \\
\hline $36-50$ & Rendah & 25 & 29,42 \\
$51-65$ & Sedang & 41 & 48,23 \\
$66-80$ & Tinggi & 19 & 22,35 \\
\hline & Jumlah & 85 & 100,00 \\
\hline
\end{tabular}

Sumber: Hasil Olahan Data Angket Penelitian, Tahun 2014

Berdasarkan data pada Tabel distribusi frekuensi di atas, jika dibandingkan dengan nilai rata-rata menunjukkan bahwa skor Kompetensi Pengawas Sekolah Menengah di Kota Tual Provinsi Maluku yang berada di bawah nilai rata-rata sebanyak 25 responden, yang berada pada nilai rata-rata sebanyak 41 responden, dan yang berada di atas nilai rata-rata sebanyak 19 responden.

Hal ini dapat pula berarti bahwa dari 85 responden yang diteliti, terdapat 19 responden atau 22,35\% yang menunjukkan Kompetensi Pengawas Sekolah Menengah di Kota Tual Provinsi Maluku berada pada kategori tinggi. Selanjutnya, ada 41 responden atau 48,23 \% yang menunjukkan Kompetensi Pengawas Sekolah Menengah di Kota Tual Provinsi Maluku berada pada kategori sedang, dan ada 25 responden atau 29,42 \% yang menunjukkan Kompetensi Pengawas Sekolah Menengah di Kota Tual Provinsi Maluku termasuk kategori rendah.

Dengan demikian, berdasarkan uraian tersebut di atas dapat dikemukakan bahwa Kompetensi Pengawas Sekolah Menengah di Kota Tual Provinsi Maluku termasuk dalam kategori sedang. 
Pelaksanaan Supervisi Akademik Pengawas Sekolah Menengah di Kota Tual Provinsi Maluku. Berdasarkan hasil analisis deskriptif diperoleh ukuran pemusatan tentang Pelaksanaan Supervisi Akademik Pengawas Sekolah Menengah di Kota Tual Provinsi Maluku, yaitu skor rata-rata $($ mean) = 37,02; median $=35,00 ;$ dan modus $=25$. Hasil ini bersesuaian dengan distribusi frekuensi dan persentase yang menunjukkan bahwa Pelaksanaan Supervisi Akademik Pengawas Sekolah Menengah di Kota Tual Provinsi Maluku berkisar 57,65 \% Dengan demikian secara kualitatif, Pelaksanaan Supervisi Akademik Pengawas Sekolah Menengah di Kota Tual Provinsi Maluku termasuk kategori rendah.

Selanjutnya, dari hasil analisis statistik deskriptif diperoleh ukuran penyebaran, yaitu skor tertinggi sebesar 63 dan skor terendah sebesar 25, dan varians sebesar 130,595. Berdasarkan perolehan ukuran-ukuran tersebut yang relatif besar, maka dapat dikatakan bahwa penyebaran data variabel Pelaksanaan Supervisi Akademik Pengawas Sekolah Menengah di Kota Tual Provinsi Maluku, cenderung bervariasi. Hal ini berarti data yang diperoleh dalam penelitian tersebar pada tiga kategori, yaitu: rendah, sedang, dan tinggi.

Adapun distribusi frekuensi dan persentase variabel Pelaksanaan Supervisi Akademik Pengawas Sekolah Menengah di Kota Tual Provinsi Maluku dapat dilihat pada tabel sebagai berikut:

Tabel 4.2. Distribusi Frekuensi dan Persentase Pelaksanaan Supervisi Akademik Pengawas Sekolah Menengah di Kota Tual Provinsi Maluku $\begin{array}{llll}\text { Interval } & \text { Kategori } & \text { Frekuensi } & \text { Persentase (\%) }\end{array}$

\begin{tabular}{cccc}
\hline & & & \\
$25-38$ & Rendah & 49 & 57,65 \\
$39-52$ & Sedang & 26 & 30,59 \\
$53-66$ & Tinggi & 10 & 11,76 \\
\hline Jumlah & & 85 & 100,00 \\
\hline
\end{tabular}

Sumber: Hasil Olahan Data Angket Penelitian, Tahun 2014 
Berdasarkan data pada Tabel distribusi frekuensi di atas, jika dibandingkan dengan nilai rata-rata menunjukkan bahwa skor Pelaksanaan Supervisi Akademik Pengawas Sekolah Menengah di Kota Tual Provinsi Maluku yang berada di bawah nilai rata-rata sebanyak 49 responden, yang berada pada nilai rata-rata sebanyak 26 responden, dan yang berada di atas nilai rata-rata sebanyak 10 responden.

Hal ini dapat pula berarti bahwa dari 85 responden yang diteliti, terdapat 10 responden atau 11,76 \% yang menunjukkan Pelaksanaan Supervisi Akademik Pengawas Sekolah Menengah di Kota Tual Provinsi Maluku berada pada kategori tinggi. Selanjutnya, ada 26 responden atau 30,59\% yang menunjukkan Pelaksanaan Supervisi Akademik Pengawas Sekolah Menengah di Kota Tual Provinsi Maluku berada pada kategori sedang, dan ada 49 responden atau 57,65 \% yang menunjukkan Pelaksanaan Supervisi Akademik Pengawas Sekolah Menengah di Kota Tual Provinsi Maluku termasuk kategori rendah. Dengan demikian, berdasarkan uraian tersebut di atas dapat dikemukakan bahwa Pelaksanaan Supervisi Akademik Pengawas Sekolah Menengah di Kota Tual Provinsi Maluku termasuk dalam kategori rendah.

\section{A. Pembahasan Hasil Penelitian}

Pendidik merupakan tenaga professional yang bertugas merencanakan dan melaksanakan proses pembelajaran, menilai hasil pembelajaran, melakukan pembimbingan dan pelatihan, serta melakukan penelitian dan pengabdian kepada masyarakat. Untuk dapat melaksanakan tugas dan tanggung jawab di atas, seorang guru dituntut memiliki beberapa kebaikan dan keterampilan tertentu. Kebaikan dan keterampilan tersebut sebagai bagian dari kompetensi profesionalisme guru. Kompetensi merupakan suatu kebaikan yang mutlak dimiliki oleh guru agar tugasnya sebagai pendidik dapat terlaksana dengan baik.

Keberhasilan proses belajar mengajar sangat tergantung kepada kebaikan guru dalam mengelola pembelajaran. Kebaikan yang dimaksud adalah 
serangkaian kompetensi yang dimiliki guru, baik yang menyangkut dengan kebaikan pribadinya, kebaikan dalam berinteraksi dengan siswa, kebaikan memilih dan menentukan media dan metode pembelajaran dan kebaikan dalam mendesain dan mengembangkan materi pembelajaran.

Proses belajar dan hasil belajar bukan saja ditentukan oleh sekolah, pola, struktur dan isi kurikulumnya, akan tetapi sebagian besar ditentukan oleh kompetensi guru yang mengajar dan membimbing mereka. Tugas guru erat kaitannya dengan peningkatan sumber daya manusia melalui sektor pendidikan, oleh karena itu perlu upaya-upaya untuk meningkatkan mutu guru untuk menjadi tenaga professional. Agar peningkatan mutu pendidikan dapat berhasil. Maka perlu peningkatan kualitas pendidikan tergantung banyak hal, terutama mutu gurunya.

Untuk menjadikan guru sebagai tenaga professional maka perlu diadakan pembinaan secara terus menerus dan berkesinambungan, dan menjadikan guru sebagai tenaga kerja perlu diperhatikan, dihargai dan diakui keprofesionalannya. Untuk membuat mereka menjadi professional tidak semata-mata hanya meningkatkan kompetensinya baik melalui pemberian penataran, pelatihan maupun memperoleh kesempatan untuk belajar lagi namun perlu juga memperhatikan guru dari segi yang lain seperti peningkatan disiplin, pemberian motivasi, pemberian bimbingan melalui supervisi, pemberian insentif, gaji yang layak dengan keprofesionalnya sehingga memungkinkan guru menjadi puas dalam bekerja sebagai pendidik.

Kompetensi guru atau prestasi kerja adalah suatu hasil kerja yang dicapai seseorang dalam melaksanakan tugas-tugas yang dibebankan kepadanya yang didasarkan atas kecakapan, pengalaman, dan kesungguhan serta waktu (Hasibuan, 2001:94). Kompetensi guru akan baik jika guru telah melakukan unsur-unsur yang terdiri dari kesetiaan dan komitmen yang tinggi pada tugas mengajar, menguasai dan mengembangkan bahan pelajaran, kedisiplinan dalam mengajar dan tugas lainnya, kreativitas dalam pelaksanaan pengajaran, kerjasama dengan semua 
warga sekolah, kepemimpinan yang menjadi panutan siswa, kepribadian yang baik, jujur dan objektif dalam membimbing siswa, serta tanggung jawab terhadap tugasnya. Oleh karena itu tugas kepala sekolah selaku manager adalah melakukan penilaian terhadap kompetensi guru. Penilaian ini penting untuk dilakukan mengingat fungsinya sebagai alat motivasi bagi pimpinan kepada guru maupun bagi guru itu sendiri.

Ada beberapa hal yang menyebabkan meningkatnya kompetensi guru, namun penulis mencoba mengkaji masalah supervisi yang diberikan oleh pengawas sekolah. Supervisi dalam hal ini adalah mengenai persepsi guru terhadap kompetensi dan pelaksanaan supervisi akademik sebagai pembinaan dan bimbingan yang diberikan oleh pengawas sekolah yang nantinya berdampak kepada kompetensi guru yaitu kualitas pengajaran.

Seperti dikatakan bahwa Supervisi pendidikan didefenisikan sebagai proses pemberian layanan bantuan professional kepada guru untuk meningkatkan kebaikannya dalam melaksanakan tugas-tugas pengelolaan proses pembelajaran secara efektif dan efesien (Bafadal, 2004:46). Dengan adanya pelaksanaan supervisi oleh pengawas sekolah diharapkan memberi dampak terhadap terbentuknya sikap professional guru. Sikap professional guru merupakan hal yang amat penting dalam memelihara dan meningkatkan profesionalitas guru, karena selalu berpengaruh pada perilaku dan aktivitas keseharian guru. Perilaku professional akan lebih diwujudkan dalam diri guru apabila institusi tempat ia bekerja memberi perhatian lebih banyak pada pembinaan, pembentukan, dan pengembangan sikap professional (Pidarta, 1996:380).

Berdasarkan hasil wawancara yang dilakukan dengan beberapa guru di sekolah yang berbeda dapat ditemukan bahwa masih banyak kendala atau persoalan yang berkaitan dengan pelaksanaan supervisi akademik pengawas sekolah pada sekolah menengah atas di kota Tual Provinsi Maluku. Dengan demikian dapat simak pada penuturan hasil wawancara peneliti dengan guru:

......." saya sudah pelaksanakan tugas selama 8 Tahun terakhir ini belum pernah marasakan bagaimana pelaksanaan supervisi oleh pengawas...... 
selanjutnya di tambahkan... yang saya lihat Cuma kehadiran pengawas ke sekolah Cuma sebatas ruang kepala sekolah tidak pernah mengunjungi kelas.......(wawancara dengan guru pada SMA Alikhlas Terpadu Tamedan Tual, tanggal 12 April 2014).

Selanjutnya pada kesempatan yang berbeda dan sekolah yang berbeda pula peneliti mewawancarai seorang guru senior yang masa kerja 25 tahun tentang kompetensi dan pelaksaan supervisi akademik pengawas di kota Tual Provinsi Maluku. Berikut ini penuturannya.

.." Kalau menurut saya berbicara menyangkut kompetensi yang dimiliki pengawas sekolah sekarang ini masih sangant rendah sekali, karena hampir semua pengawas yang ada pada Dinas Pendidikan Pemuda dan Olahraga Kota Tual sekarang ini merupakan mantan-mantan kepala sekolah yang tinggal menunggu masa pensiun... jadi bagaimana dengan pengembangan kompetensi pengawasnya...kalau dipaksa kerja lagi maka akan mempengaruhi kondisi kesehatan mereka ..... mungkin saja pengetahan tentang komputer tidak ada ... bagaimana kalau mau melatih guru-guru kalau pengawas sendiri tidak mengusai komputer. ...dan yang paling penting adalah tidak pernah ada pelatihan atau pembimbingan tentang penyusunan Penelitian tindakan Kelas (PTK) saya sudah Golongan IV/ A sudah masuk masuk 9 tahun ini belum naik golongan ke IV/B lagi karena harus ada penulisan.....sebagai sarannya masalah ini harus diperhatikan oleh pengawas kedepan..... (Hasil wawancara dengan guru pada SMKN 1 Tual, 28 april 2014).

Dengan demikian secara umum persoalan tersebut meliputi : kualitas kompetensi dan supervisi akademik pengawas sekolah yang masih tergolong sedang. Padahal tujuan supervisi untuk membantu guru-guru melihat dengan jelas tujuan pendidikan dan berusaha mencapai tujuan pendidikan itu dengan membina dan mengembangkan metode-metode dan prosedur pengajaran yang lebih baik.

Berdasarkan hasil penelitian, untuk menjawab masalah penelitian pertama yang berbunyi bagaimana kompetensi supervisi akademik yang dimiliki oleh pengawas sekolah menengah berdasarkan persepsi guru di Kota Tual 
Provinsi Maluku, dan bagaimanakah pelaksanaan supervisi akademik pengawas sekolah menengah berdasarkan persepsi guru di Kota Tual Provinsi Maluku, maka yang dimaksudkan adalah komunikasi yang dilakukan oleh pengawas sekolah kepada guru dalam menyusun kurikulum, observasi di kelas dan pelatihan/ pembimbingan untuk penilaian tindakan kelas. Supervisi pengawas sekolah ketika mengadakan kunjungan kelas, komunikasi pengawas sekolah ketika mengadakan kunjungan observasi dan komunikasi pengawas sekolah ketika memecahkan masalah. Ini sejalan dengan hasil wawancara dengan koordinator pengawas sekolah di sekolah menengah di kota Tual Provinsi Maluku yang dikatakan bahwa :

“.....sebagai pengawas sekolah senantiasa melaksanakan pemantauan terhadap aktivitas guru dalam proses pembelajaran dan memberikan tindak lanjut terhadap hasil pemantauan yang dilakukannya." (Hasil wawancara dengan Korwas, 26 April 2014)

Apa yang dikemukakan pengawas sekolah sejalan dengan sasaran supervisi bahwa pemantauan terhadap aktivitas guru dalam pelaksanaan pembelajaran. Seiring dengan itu dikatakan pula bahwa :“....sesuai dengan kegiatan supervisi maka diadakan pelatihan /pembimbingan dalam menyusun silabus, RPP serta penggunaan strategi pembelajaran juga untuk penggunaan media pembelajaran."(Hasil Wawancara dengan Koordinator pengawas, 26 April 2014)

Dalam arti kata, bahwa pelaksanaan supervisi akademik sekolah menengah di Kota Tual Provinsi Maluku sering dilakukan oleh pengawas sekolah.

Berdasarkan dari hasil penelitian yang dilakukan peneliti pada responden dalam hal ini guru pada sekolah menengah di Kota Tual Provinsi Maluku pada hasil kuisioner tentang pelaksanaan supervisi akademik pengawas sekolah berada pada kategori rendah. Hal ini disebabkan karena frekuensi pengawas sekolah dalam memantau rencana pembelajaran guru, memantau kesesuaian perangkat pembelajaran dengan pelaksanaan hanya 1-2 kali saja 
dalam satu semester. Sejalan dengan hasil wawancara yang dilakukan peneliti dengan kepala sekolah.

“....kunjungan pengawas sekolah di sekolah kami kadangkala datang memantau pelaksanaan pembelajaran hanya awal semester dan bahkan hanya menjelang pelaksanaan semester." (Hasil Wawancara dengan kepala Sekolah SMAN 2 Tual , 12 April 2014)

Senada dengan itu peneliti melaksanakan wawancara dengan salah satu kepala sekolah menengah kejuruan ternyata sama dengan wawancara dengan kepala sekolah lainnya.

“....kunjungan pengawas sekolah di sekolah kami kadangkala datang memantau pelaksanaan pembelajaran hanya awal semester dan bahkan hanya menjelang pelaksanaan semester.” Bahkan kadang kala saya telepon/sms mohon kesediaan pengawas berkunjung ke sekolah saya dulu. (Hasil wawancara Kepala Sekolah SMKN 1 Tual, 28 April 2014)

Setiap aparatur termasuk pengawas sekolah yang diberikan tugas diharapkan mampu menunjukkan kinerja yang baik dan memberikan konstribusi yang maksimum terhadap pencapaian tujuan organisasi. Kinerja adalah hasil kerja yang dapat dicapai oleh seseorang atau kelompok orang dalam suatu organisasi, sesuai dengan wewenang dan tanggung jawab masing-masing, dalam rangka upaya mencapai tujuan organisasi yang bersangkutan secara legal. Tidak melanggar hukum dan sesuai dengan moral maupun etika .

Berkaitan dengan kinerja maka pengawas sekolah sebagai aparatur negara, ada tiga aspek yang dapat diketahui yaitu :

1. Adanya kegiatan tugas dan pekerjaan yang merupakan tanggung jawab.

2. Kejelasan hasil yang diharapkan dari suatu pekerjaan.

3. Waktu yang diperlukan menyelesai suatu pekerjaan agar hasil yang diharapkan dapat terwujud.

Berdasarkan pemahaman tersebut, maka pengawas sekolah harus menyadari bahwa pekerjaan yang dilakukannya harus membawakan suatu hasil. Sehingga supervisi yang dilakukan sebagai salah satu perwujudan kinerja dapat diuraikan 
sebagai hasil kerja atau kemampuan kerja yang diperlihatkan seseorang, sekelompok orang, atas pekerjaan pada waktu tertentu. Kinerja dapat berupa produk akhir (barang dan jasa) dan bentuk prilaku, kecakapan, kompetisi, sarana dan keterampilan spesifik yang dapat mendukung pencapaian tujuan dan sasaran organisasi.

Giddings (2012) Dalam perspektif Manajemen Sumber Daya manusia, kegiatan penilaian kinerja merupakan salah satu rangkaian dari siklus manajemen kinerja. Kegiatan penilaian kinerja pada dasarnya merupakan upaya untuk memberikan jaminan bahwa setiap pegawai/karyawan dapat bekerja secara efektif, efisien dan produktif sesuai dengan tugas dan fungsi masing-masing.

Profesi pengawas sekolah memiliki tugas melayani masyarakat dalam bidang pendidikan. Tuntutan profesi ini memberikan layanan yang optimal dalam bidang pendidikan kepada masyarakat. Secara khusus pengawas sekolah di tuntut untuk memberikan layanan professional kepada guru agar tujuan pembelajaran tercapai. Sehingga pengawas sekolah yang dikatakan profesional adalah orang yang memeiliki kemampuan dan keahlian khusus dalam bidang kepengawasan sehingga ia mampu melaksanakan tugas dan fungsinya sebagai pengawas sekolah dengan kemampuan maksimal.

Untuk melaksanakan tugas dan fungsinya dengan baik agar dapat meningkatkan mutu pendidikan maka pengawas sekolah harus memiliki kompetensi yang harus dikuasai sebagai suatu jabatan profesional. Dengan memiliki sikap yang profesional, pengawas sekolah diharapkan dapat meningkatkan kinerjanya. Dalam hal melakukan supervisi akademiknya sebagai pengawas sekolah.

Berdasarkan hasil penelitian menunjukkan bahwa kompetensi pengawas sekolah menengah atas di kota Tual Provinsi Maluku tergolong sedang, hanya sebagian kecil saja yang tinggi dan rendah. Kurangnya kompetensi pengawas tersebut ditunjukkan dari masih ada pengawas yang kurang memahami dalam hal menyusun silabus dan rencana pembelajaran yang masih kurang. Hal ini karena sebagian besar pengawas kurang memiliki 
pemahaman yang baik dalam menyusun rencana pembelajaran. Ini semua tidak lepas dari pengalaman yang diperolehnya selama kuliah dan pengalaman selama menjadi pengawas. Karena kompetensi yang dimiliki pengawas sekolah dalam kategori sedang Sehingga masih banyak guru kuantitas dalam penyusunan rencana pembelajaran masih tergolong rendah, karena kurangnya pembinaan ke sekolah-sekolah, ini terbukti banyak guru yang menyusun rencana pembelajaran ketika mendekati akreditasi atau adanya supervisi pengawas sekolah. Hal ini terjadi karena merasa bahwa rencana pembelajaran selama ini hanya formalitas administratif dalam pendidikan. Mereka lebih mementingkan cara pengajarannya. Alasan lainnya mungkin karena sudah memiliki pengalaman yang lebih lama dalam mengajar dan melakukan rutinitas mengajar yang sama, maka kurang perlu menggunakan rencana pembelajaran karena bagi guru tanpa rencanapun materi dapat selesai diajarkan sesuai dengan kalender yang ditetapkan. Hampir semua guru lebih mementingkan pada kualitas pembelajaran, bukan pada pembuatan rencana pembelajaran. Dalam pelaksanaan interaksi belajar mengajar hampir semua guru baik melaksanakan dengan sangat baik. Hal ini disebabkan karena kebaikan berinteraksi yang tinggi, kebaikan menyampaikan materi, kebaikan dalam memotivasi siswa untuk belajar. Ini semua juga tidak lepas dari pengalaman yang didapat selama mengajar.

Tidak hanya interaksi dalam pembelajaran, dalam hal melakukan penilaian prestasi belajar, hampir semua guru melaksanakan penilaian secara baik. Hal ini terbukti dari pelaksanaan penilaian ulangan harian yang dilaksanakan setiap pokok bahasan dan ada pula yang melaksanakan setiap kali pertemuan. Mereka memiliki kebaikan yang tinggi dalam menganalisis hasil penilaian, melakukan laporan penilaian (Iskandar 2016).

Setelah penilaian dilakukan, tindak lanjut hasil penilaian juga dilaksanakan secara sangat baik. Mereka memiliki kebaikan yang tinggi dalam menyusun program tindak lanjut, melaksanakan remedial dan mengklasifikasikan kebaikan siswa. 
Hal itu akan tercapai manakala Kompetensi pengawas sekolah berada pada kategori tinggi .maka tentu guru akan memiliki wawasan pendidikan yang baik, memahami hubungan pendidikan dan pengajaran serta memiliki kebaikan yang tinggi dalam memahami fungsi sekolah, meskipun dalam mengembangkan profesinya masih tergolong kurang. Hal ini disebabkan karena hampir semua guru belum melakukan penelitian guna menunjang profesinya. Mereka lebih menunjukkan pada penguasaan akademik dengan cara mempersiapkan materi yang akan disajikan untuk siswa dan menguasai bahan kajiannya.

Supervisi akademik merupakan bagian yang tidak terpisahkan dari seluruh proses dministrasi pendidikan yang ditunjukkan terutama untuk mengembangkan efektivitas kompetensi personalia sekolah yang berhubungan tugas-tugas utama pendidikan. Supervisi akademik yang merupakan usaha dari pengawas sekolah dalam memimpin guru-guru dalam memperbaiki pengajaran, termasuk menstimulasi, menyeleksi pertumbuhan jabatan dan perkembangan guru-guru serta merevisi tujuan-tujuan pendidikan, bahan pengajaran dan metode serta evaluasi pengajaran belum dirasakan manfaat sepenuhnya oleh guru.

Pengawas sendiri masih merasakan banyak faktor yang sangat mempengaruhi kompetensi dan pelaksanaan supervisi akademik pengawas di kota Tual saat ini adalah pengawas tidak berupaya untuk mengembangkan kompetensi dirinya maupaun kelembagaannya sehingga sangat berdampak pada pelaksanaan supervisi akademik pengawas ke sekolah-sekolah, usia pengawas yang sudah berlanjut dan hanya tinggal menanti masa pensiun, perhatian pemerintah daerah yang belum optimal dalam mendukung kegiatan kepengawasan, masalah biaya, fasilitas transpotasi sebagai penunjang aktivitas pengawas, area lokasi kantor Dinas pendidikan yang merupakan area sengketa yang mengakibatkan kegiatan perkantoran sewaktu-waktu terhenti karena disegel oleh pemilik area lokasi perkatoran dan aktivitas kegiatan perkatoran tidak berjalan secara baik sehingga sangat berdampak pada peningkatan mutu pendidikan di kota Tual Provinsi Maluku. 


\section{Kesimpulan}

Berdasarkan deskripsi, hasil analisis data, dan pembahasan dalam penelitian ini, maka kesimpulan dari penelitian ini sebagai berikut:

1. Kompetensi Pengawas Sekolah Menengah di Kota Tual Provinsi Maluku berada pada kategori sedang. Hal tersebut terlihat pada hasil observasi, wawancara dan data dokumentasi yang dilakukan serta hasil data angket yang diperoleh dari guru tentang kompetensi pengawas sekolah dalam memantau, menilai, membimbing penyusunan kurikulum, mengadakan kunjungan kelas, dan pemecahan masalah.

2. Pelaksanaan supervisi akademik pengawas Sekolah Menengah di Kota Tual Provinsi Maluku berada pada kategori belum sesuai dengan harapan. Supervisi pengawas belum efektif dilaksanakan diakibatkan dari komitmen dan motivasi pengawas yang belum terlalu tinggi. Para pengawas juga belum mampu menjalin komunikasi yang erat dan harmonis dengan para kepala sekolah dan para guru di sekolah binaannya, sehingga tidak nampak adanya kerjasama yang saling mendukung untuk mewujudkan pelaksanaan supervisi akademik yang efektif.

\section{Saran}

Sehubungan rumusan kesimpulan di atas, maka berikut ini dikemukakan beberapa saran sebagai berikut:

1. Kepada Pemerintah Kota Tual Provinsi Maluku agar dapat memperhatikan:

a. Penetapan rekrutmen pengawas berdasarkan PERMEN Nomor 12 Tahun 2007.

b. Pengadaan sarana transportasi roda dua bagi pengawas agar dapat memperlancar aktivitas pengawas untuk berkunjung ke sekolah.

c. Menyelesaikan persoalan sengketa area lokasi perkantoran Dinas Pendidikan Pemuda dan Olahraga sehingga tidak menghambat aktivitas perkatoran yang merupakan jantung pendidikan di Kota Tual.

2. Dinas Pendidikan Pemuda dan Olahragan Kota Tual, kiranya dapat memperhatikan: 
a. Kualitas kompetensi pengawas sekolah dalam hal mengadakan pelatihanpelatihan yang masih kurang terhadap pengawas sekolah sehingga terwujudnya kompetensi akademik pengawas yang memuaskan. Dinas Pendidikan Pemuda dan Olahraga kota Tual provinsi Maluku.

b. Kiranya dapat segera merealisasikan peraturan perundangan yang berlaku dalam melaksanakan rekrutmen calon pengawas sekolah, agar diperoleh para pengawas sekolah yang profesional guna mendukung terwujudnya penyelenggaraan pendidikan yang bermutu di kota Tual. Selain itu, diharapkan lebih intens dalam meningkatkan perhatian dan pembinaan pada profesi pengawas sekolah sehingga peran pengawas sebagai penjamin mutu pendidikan di sekolah-sekolah dapat lebih diberdayakan.

c. Kepala Dinas Pendidikan Pemuda dan Olahraga Kota Tual di harapkan dapat menginstruksikan kepada pengawas sekolah agar melaksanakan tugas supervisi akademik kepada guru secara baik dan bertanggung jawab. Perlu memberikan sanksi kepada pengawas sekolah yang tidak melaksanakan tugas dan tanggung jawabnya sebagai pengawas rumpun mata pelajaran. Oleh karena itu, Dinas Pendidikan hendaknya menyusun kegiatan-kegiatan peningkatan kualitas guru pada Sekolah Menengah di Kota Tual Provinsi Maluku.

3. Kepada Pengawas Sekolah Menengah di Kota Tual Provinsi Maluku, kiranya pada waktu mendatang perlu secara aktif meningkatkan komitmen, motivasi dan kemampuan profesionalitas pengawas walaupun harus dilakukan secara mandiri. Tugas yang mulia ini harus dibarengi dengan kemampuan yang tinggi, dan dapat terefleksikan dalam kesungguhan melaksanakan supervisi secara sistematis, terjadwal, terus-menerus dan berkesinambungan. Pelaksanaan supervisi akademik perlu dilakukan setiap saat dan berkesinambungan untuk dapat meningkatkan kompetensi guru, sebagai wujud tanggung jawab pengembangan pendidikan di sekolah. Selain itu, diperlukan jalinan komunikasi yang erat dan hramonis dengan kepala sekolah, para guru di 
sekolah binaan, dan Kepala Dinas Dikpora sehingga tercipta situasi kerja yang kondusif.

4. Kepada kepala sekolah dan guru pada sekolah menengah di Kota Tual Provinsi Maluku, kiranya perlu meminta kepada koordinator pengawas atau Kepala Dinas Pendidikan agar dapat mengaktifkan pengawas rumpun mata pelajaran yang bertugas pada sekolah menegah di Kota Tual Provinsi Maluku dan kepala sekolah dan guru hendaklah memberikan kesempatan kepada pengawas sekolah untuk dapat mensosialisasikan program kerja pengawas baik pada rapat kerja sekolah, maupun pada rapat-rapat lain yang dilaksanakan oleh sekolah. Guru kiranya selalu meningkatkan kompetensi dalam melaksanakan aktivitas di sekolah sebagai tanggung jawab pengembangan pendidikan serta peningkatan profesionalismenya. Guru perlu memahami secara penuh kehadiran pengawas di sekolah yang melaksanakan supervisi akademik sebagai salah satu sarana untuk membantu meningkatkan kualitas profesional tenaga pendidik. Kepala sekolah dan para guru diharapkan dapat lebih membuka diri dengan menjadikan pengawas Sekolah Menengah sebagai mitra kerja dalam meningkatkan kualitas penyelenggaraan pendidikan dan peningkatan profesional guru.

\section{REKOMENDASI}

Berdasarkan hasil penelitian yang dilakukan dengan judul Analisis Kompetensi dan Pelaksanaan Supervisi akademik pengawas sekolah menengah di kota Tual Provinsi Maluku, maka kesimpulan diperoleh dan hasil temuan dilapangan yang merupakan faktor penghambat kompetensi pengawas berada pada kategori sedang, dan Pelaksanaan kompetensi pengawas berada pada kategori belum sesuai dengan harapan adalah belum adanya perhatian serius dari Pemerintah Daerah Kota Tual dan Dinas Pendidikan kota Tual terkait permasalahan penelitian sehingga ada kesempatan ini peneliti merekomendasikan kepada: 
1. Pemerintah Daerah kota Tual Provinsi Maluku agar dapat memperhatikan.

a. Rekrutmen calon pengawas berdasarkan PERMEN Nomor 12 Tahun 2007 tentang Standar Pengawas Sekolah/Madrasah.

b. Biaya pelaksanan tugas pengawas ke sekolah-sekolah.

c. Pengadaan kendaraan roda dua bagi pengawas sekolah guna memperlancar pelaksanaan tugas pengawasan ke sekolah-sekolah binaanya.

d. Menyelesaikan persoalan sengketa area kantor Dinas Pendidikan Pemuda dan Olahraga Kota Tual kiranya tidak menghambat aktivitas perkantoran terutama aktivitasa pendidikan di Kota Tual Provinsi maluku.

2. Dinas Pendidikan Pemuda dan Olahraga Kota Tual agar dapat memperhatikan:

a. Rekrutmen calon pengawas harus berdasarkan PERMEN Nomor 12 Tahun 2007 tentang Standar Pengawas Sekolah/Madrasah (aspek kompetensi, kualifikasi pendidikan, usia bagi calon pengawas sekolah).

b. Mengaktifkan pengawas rumpun mata pelajaran sehingga dapat memperlancar proses pembinaan bagi guru sekolah menengah di Kota Tual Provinsi Maluku.

c. Meningkatkan mutu kompetensi pengawas melalui keikutsertakan pengawas dalam kegiatan tingkat Kabupaten/Kota, Provinsi maupun Nasional melalui pelatihan dan pembimbingan bagi pengawas.

d. Pengadaan Alat Tulis Kantor(ATK) guna memperlancar kegiatan adminstrasi pengawas dalam pelaksanaan penyusunan pelaporan hasil kegiatan kepengawasan.

\section{Ucapan Terima kasih}

Penulis menyadari bahwa peneltian ini tidak akan terwujud sebagaimana adanya tanpa bantuan dan dorongan dari berbagai pihak. Oleh karena itu penulis mengucapkan terima kasih sebagai tanda penghargaan yang tulus ikhlas kepada yang terhormat Dr. Patahuddin, M.Pd., selaku Pembimbing I, dan Prof. Dr. Jokebet Saludung. M. Pd. selaku pembimbing II, atas keikhlasannya meluangkan waktu, tenaga dan pikirannya untuk memberikan bimbingan, petunjuk, saran dan motivasi kepada penulis selama penyusunan tesis ini. Ucapan terima kasih pula 
disampaikan juga kepada dewan penguji, yaitu Prof. Dr. Andi Ihsan, M. Kes, danProf. Dr. Ruslan, M. Pd, yang banyak memberikan masukan yang sangat berarti dalam penyempurnaan peneltian ini.

Pada kesempatan ini, perkenankan pula penulis mengucapakan terima kasih yang tulus kepada Prof. Dr. H. Arismunandar, M. Pd, selaku Rektor Universitas Negeri Makasar yang telah menerima penulis untuk menimbah ilmu di Universitas Negeri Makassar. Prof. Dr. Jasrudidin, M. Si. Prof. Dr. H. Suradi Tahmir, M. S, dan Prof. Dr. Andi Ihsan, M. Si., masing-masing selaku Direktur, Asisten Direktur I, Asisten Direktur II, Prof. Dr. Ruslan, M. Pd, selaku Ketua Prodi Penelitian dan Evaluasi Pendidikan yang telah memberikan pelayanan yang maksimal bagi penulis selama kuliah di Program Studi Penelitian dan Evaluasi Pendidikan. Dosen Program Studi Penelitian dan Evaluasi Pendidikan yang telah memberikan bekal ilmu pengetahuan sehingga penulis dapat melaksanakan penelitian dan penyelesaian studi dengan baik. Segenap karyawan PPs UNM yang telah memberikan pelayanan kepada penulis selama menjalani proses perkuliahan di Program Studi Penelitian dan Evaluasi Pendidikan.

Terima kasih yang tulus juga penulis sampaikan kepada Dit PeTK Dikmen. Direktorat Jenderal Pendidikan Menengah, Kementrian Pendidikan dan Kebudayaan Republik Indonesia atas pemberian beasiswa penuh pada penulis selama dua Tahun.

Ucapan terima kasih pula samapaikan kepada Pemerintah Kota Tual yang telah bersedia memberikan izin penelitian kepada penulis sehingga penyusunan tesis ini dapat terselesaikan dengan baik. Kepala Dinas Pendidikan Pemuda dan Olahraga Kota Tual atas pelayanannya kepada penulis selama penelitian dan penyusunan tesis ini. Kepala Sekolah Menengah beserta staf pengajar di Kota Tual yang banyak membantu penulis dalam memperoleh data penelitian demi penyelesaian penyusunan penelitian ini. 


\section{DAFTAR PUSTAKA}

Aqib, Zainal dan Rohmanto Elham. 2007. Membangun Profesionalisme Guru dan Pengawas Sekolah. Lamongan: CV. Yrama Widya.

Asmani, Jamal Ma’mur. 2009. Tips Menjadi Guru Kreatif, Inspiratif, dan Inofatif. Yogyakarta: Diva Press.

Badafal, Ibrahim, 2004. Peningkatan Profesionalime guru. Jakarta: Bumi Aksara.

Creswell, John W. 2012. Researh Design: Pendekatan Kualitatif, Kuantitatif, dan Mixed. California: SAGE Publication

Daresh. 1989. Supervisi Pendidikan. Jakarta: Ghalia Indonesia

Depdiknas, 2003, UU RI Nomor 20 Tahun 2003 Tentang Sistem Pendidikan nasional: Jakarta.

Iskandar, 2008. Metodologi Penelitian Pendidkan dan Sosial.Jakarta: Gaung Persada Pres.

Iskandar, Akbar. 2016. "Membangun Aplikasi Placement Test." Jurnal Inspiration 6(1):65-80.

Iskandar, Akbar and Ahmad Rudi. 2017. "Penyetaraan Tes Soal Potensi Akademik Berdasarkan Teori Respon Butir Menggunakan Software R Di STMIK AKBA.” Educational Science and Technology 3(2):145-52.

Moleong, L. J. 2002. Metode Penelitian Kualitatif. Bandung: Remaja Rosdakarya.

Mulyasa, E. 2007, Menjadi kepala Sekolah Profesional. Bandung: Rosda Karya.

Pidarta, Made. 1996. Pemikiran tentang Supervisi Pendidikan. Jakarta: Bumi Aksara.S

Purwanto, M. Ngalim. 2004. Administrasi dan Supervisi Pendidikan. Bandung: Remaja Rosdakarya

Pusat Pengembangan Tenaga Kependidikan. 2011. Materi Pelatihan Penguatan kemampuan kepala seklah . Jakarta: Badan pengembangan sumber Daya Manusia dan Penjamin Mutu Pendidikan, Kementrian Pendidikan nasional.

1987. Administrasi dan Supervisi Pendidikan, Jakarta: Nasco. 
1997, Petunjuk Pelaksanaan Jabatan Fungsional Pengawas dan Angka Kreditnya. Jakarta.

2007, Peraturan Mentri Pendidikan Republik Indonesi Nomor 12 Tahun 2007 Tentang Standar pengawas Sekolah/ Madrasah: Jakarta.

2001, Proses Belajar Mengajar: Jakarta: Bumi aksara.

Subari. 1994. Supervisi Pendidikan, Jakarta: Bumi Aksara..

Sudjana, H Nana. 2011. Supervisi PendidikaN : Konsep dan Aplikasinya Bagi Pengawas Sekolah. Bekasi : Binamitra Publishing Cikarang.

Sudjana, H Nana. 2012. Pengawas dan kepengawasan: Memahami Tugas Pokok, Fungsi, Peranan dan Tanggung Jawab Pengawas Sekolah. Bekasi : Binamitra Publishing Cikarang.

Sugiyono, 2005. Memahami Penelitian Kualitatif, Bandung : Alfabet 2012. Pengawas dan Kepengawasan. Bekasi: Binamitra Publishing Cikarang.

Tattah, Nanang. 2008. Landasan Manajemen Pendidikan. Bandung : Rorda Karya

Tenrinengsih, Andi. 2010. Supervisi Pengajaran, Motivasi Kerja, Kinerja Guru, dan Prestasi Belajar Siswa. Jakarta: Penerbit Belton Express. 